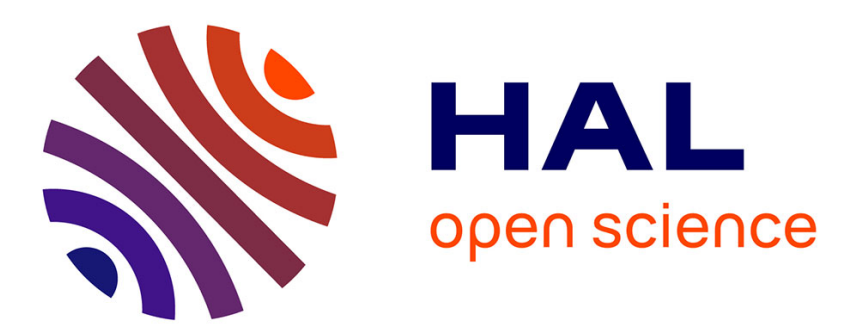

\title{
Geologic evidence for the prolongation of active normal faults of the Mona Rift into northwestern Puerto Rico.
} Jean-Claude Hippolyte, P. Mann, N. Grindlay

\section{To cite this version:}

Jean-Claude Hippolyte, P. Mann, N. Grindlay. Geologic evidence for the prolongation of active normal faults of the Mona Rift into northwestern Puerto Rico.. Geological Society of America Special Papers, 2005, 385, pp.161-171. hal-00100359

\section{HAL Id: hal-00100359 \\ https://hal.science/hal-00100359}

Submitted on 26 Sep 2006

HAL is a multi-disciplinary open access archive for the deposit and dissemination of scientific research documents, whether they are published or not. The documents may come from teaching and research institutions in France or abroad, or from public or private research centers.
L'archive ouverte pluridisciplinaire HAL, est destinée au dépôt et à la diffusion de documents scientifiques de niveau recherche, publiés ou non, émanant des établissements d'enseignement et de recherche français ou étrangers, des laboratoires publics ou privés. 


\title{
Geologic evidence for the prolongation of active normal faults of the Mona Rift into northwestern Puerto Rico
}

\author{
J.-C. Hippolyte ${ }^{1}$, P. Mann ${ }^{2}$ and N. Grindlay ${ }^{3}$ \\ ${ }^{1}$ UMR CNRS 5025 Laboratoire de Géodynamique des Chaînes Alpines \\ Université de Savoie - Campus Scientifique Technolac \\ 73376 Le Bourget du Lac Cedex, France \\ fax: (33) 0479758777 \\ tel: (33) 0479758715 \\ e-mail: Jean-Claude.Hippolyte@univ-savoie.fr \\ ${ }^{2}$ Institute for Geophysics, University of Texas at Austin \\ 4412 Spicewood Springs Road, Bldg. 600 \\ Austin, TX 78759 USA \\ ${ }^{3}$ Center for Marine Science, University of North Carolina Wilmington \\ Wilmington, NC 28409
}

\begin{abstract}
Topography, bathymetry, regional structural observations, and fault slip measurements support the idea that the Mona rift is an active, offshore extensional structure separating a colliding area (eastern Hispaniola) from a subducting area (northwestern Puerto Rico). Near the city of Aguadilla in northwestern Puerto Rico, paleostress reconstruction through fault slip analysis demonstrates that the Mona rift is opening in an E-W direction. Fault slip analysis also indicates that this opening is oblique in the southern part of the rift. We propose that oblique rifting results from accommodation of E-W extension by oblique right-lateral reactivation of previously mapped, northwest-trending Eocene basement convergent structures (Aguadilla faults, Cerro-Goden fault). The evolution of the stress field during the Miocene and the present E-W opening of the Mona rift support the assumption that the Miocene $25^{\circ}$ counterclockwise rotation of Puerto Rico has stopped and that this island is presently moving to the east relative to the colliding Hispaniola.
\end{abstract}




\section{INTRODUCTION}

\section{Plate Boundary Zone}

The island of Puerto Rico is located within a 250-km-wide deformation zone formed at the northern boundary between the Caribbean and North American plates (Fig. 1). Eastward motion of the Caribbean plate at a rate of about $2 \mathrm{~cm} / \mathrm{yr}$ relative to the North American plate determined by recent GPS measurements (DeMets et al., 2000) indicates that this active deformation within this plate boundary zone is largely controlled by leftlateral strike-slip faulting. Because Puerto Rico and eastern Hispaniola are underthrust in the north by North American lithosphere and in the south by Caribbean lithosphere (Fig. 1), it is likely that Puerto Rico behaves independently from the two larger plates.

\section{Microplate Tectonics.}

On the basis of seismotectonic and structural data, three microplates have been identified and named within this diffuse boundary zone. From west to east, the microplates include: Gonave, Hispaniola and Puerto Rico-Virgin Islands (e.g. Byrne et al., 1985; Manson and Scanlon, 1991; Mann et al., 1995). Of particular interest to this study is the nature of the active tectonic transition between Hispaniola, where collisional and strike-slip deformation is occurring (e.g. Mann et al., 1995) and Puerto Rico-Virgin Islands where subduction occurs (McCann, this volume).

One regional model for deformation is that collision of Hispaniola with the Bahamas bank pins or impedes the eastward motion of the Hispaniola segment of the plate boundary zone. Tectonic pinning or collision results in localized extension in the marine straits (Mona Passage) between Hispaniola and Puerto Rico (Vogt et al., 1976). This idea is consistent with GPS measurements that indicate $5+/-4 \mathrm{~mm} / \mathrm{y}$ of opening between the two microplates (Jansma et al., 2000) (Fig. 1). These authors suggest that the approximately E-W-induced extension is accommodated by the Mona rift (fig. 1).

Mechanisms for Openin the Mona rift.

The kinematic of opening for the Mona rift is not well constrained. Two earthquake focal plane mechanisms near the Mona rift indicate SE-trending and ESEtrending $\mathrm{T}$ axes (Fig. 1). These trends contrast with the shape of the rift that corresponds to a deep canyon that trends N-S in the north and SE in the south (Fig. 2). Moreover, the main neotectonic event shown by the geology of Puerto Rico is the arching of a Miocene reefal carbonate platform suggestive of N-S shortening (van Gestel et al., 1998).

In this paper we present structural data in Northwestern Puerto Rico. As seen on the bathymetric map in Figure 2, at $25 \mathrm{~km}$ to the NW of Puerto Rico the Mona rift changes trend abruptly from NS to NW-SE. Northwestern Puerto Rico is the onshore area 
the closest of the Mona rift and can yield information that is not possible to obtain offshore. We describe recent onshore faulting in this region that could then be used in turn to predict the locations, trends, opening directions, and earthquake hazards of the offshore faults. We present: 1) field-based fault observations of the fault kinematics of recent, onland faults belonging to the Mona Rift fault system; 2) the results of the first fault slip measurements from Neogene carbonate rocks in Puerto Rico; and 3) we analyze the fault slip measurements in terms of stresses using the Direct Inversion Method of Angelier (1990). This method allows to calculate an average reduced stress tensor (orientation of the stress axes $\sigma 1, \sigma 2$ and $\sigma 3$ and the ratio $\Phi=(\sigma 2-\sigma 3) /(\sigma 1-\sigma 3)$ ) with a homogeneous fault slip data set. Within a heterogeneous fault slip data set, and taking into account field observations, it is possible to separate different data subsets corresponding to successive fault generations. It is therefore possible to reconstruct the tectonic and paleostress evolution of this area from Eocene to recent times.

\section{IMPORTANCE OF THE MONA PASSAGE FOR UNDERSTANDING THE} GEODYNAMICS OF NORTHWESTERN CARIBBEAN.

Structural setting of Puerto Rico.

The Puerto Rico-Virgin Islands (PRVI) microplate is limited to the north and south by subduction zones, and to the east and the west by zones of probable extension or transtension (Fig. 1). To the north, the microplate is underthrusted by North America lithosphere along the EW-striking Puerto Rico trench that reaches a water depth of about $8 \mathrm{~km}$ (Fig. 1). To the south, the PRVI microplate is bounded by the Muertos trough, an EW-striking, 5-km-deep bathymetric feature, where northward subduction of Caribbean lithosphere is occurring (Ladd et al., 1977; Byrne et al., 1985). At least $40 \mathrm{~km}$ of underthrusting of the Caribbean plate occurs south of eastern Hispaniola (Ladd et al., 1977). This value decreases toward the east and underthrusting is ultimately replaced by extension in the Virgin Island basin complex (Masson and Scanlon, 1991). This basin along with the Anegada Passage probably form a transtensional zone that may define the eastern boundary of the PRVI microplate (Jansma at al., 2000).

The western boundary of the PRVI microplate in the Mona Passage is mainly characterized by NW-trending normal faults (e.g. Case and Holcombe, 1980; Masson and Scanlon, 1991; Grindlay et al., 1997) and by three (Yuma, Cabo Rojo and Mona) roughly N-S trending deep canyons interpreted as late Neogene rift structures (e.g., Masson and Scalon, 1991; Grindlay et al., 1997; van Gestel et al., 1998). Of these rifts, by far the most morphologically-prominent is the Mona rift (Fig. 2). It is likely that the box-shaped profile and the steep walls of the Mona rift are controlled by N-S and NW-SE-oriented 
faults. However, only a few other N-S-trending faults have been recognized in the Mona Passage (Manson and Scalon, 1991; Grindlay et al., 1997; van Gestel et al., 1998).

There is no drill core to constrain the age of these onland faults despite their apparent activity in late Neogene times. Because the offshore faults can be seen cutting seismic lines throught the entire Neogene carbonate section, the onland faults are also inferred to be Pliocene-Quaternary in age (e.g. van Gestel et al., 1998).

\section{Present deformation.}

The historical seismicity in the Mona Passage (McCann et al., this volume) and the steep walls of the Mona rift (Fig. 2) support the interpretation that this structure remains active today. In 1918, a significant (Ms 7.3) earthquake occurred offshore of NW Puerto Rico (Pacheco and Sykes, 1992) and was followed by a 4-6m tsunami in western Puerto Rico (Fig. 1). The epicenter of this earthquake is thought to have been located northwest of Puerto Rico; the generation of a tsunami is consistent with the hypothesis that normal faults are active in the Mona rift. Accordingly, Mercado and McCann (1998) used a rupture along four segments of a N-S trending normal fault in the Mona rift to numerically simulate the tsunami run-up in western Puerto Rico.

Based on GPS measurements and on two-dimensional elastic modeling of strain accumulation on active faults across Hispaniola, Jansma et al. (2000) inferred an eastward motion of Puerto Rico relative to central Hispaniola of $5+/-4 \mathrm{~mm} / \mathrm{y}$. Assuming all motion is accommodated across the Mona rift (whose total tectonic extension is about $6 \mathrm{~km}$ - van Gestel et al., 1998) and assuming that the rate of opening is constant, these authors estimate that minimum and maximum ages of the Mona Rift are $<1$ million and 6 million years, respectively.

Present-day east-west extension in the Mona Passage apparently disagrees with geodynamic models that predict an anticlockwise rotation of the PRVI microplate within a broad left-lateral shear zone (Fink and Harrison, 1972; Masson and Scanlon, 1991; Huerfano, 1995). Such rotation explains extensional structures of the Anegada Passage, the variation of shortening in the Muertos Trough, and predicts extension to the northwest in the Puerto Rico trench (Schell and Tarr, 1978; Masson and Scanlon, 1991). Paleomagnetic data from Cretaceous and Eocene rocks exposed in Puerto Rico effectively record $>45^{\circ}$ of counterclockwise rotation since the Eocene and $24^{\circ}$ since the Miocene (Fink and Harrison, 1972; Van Fossen et al., 1989; Reid et al., 1991).

It is possible that this rotaton has ceased. Because the paleomagnetic declination of Pliocene carbonates from northern Puerto Rico was not statistically different from that expected $\left(1.7 \pm 9.9^{\circ}\right)$, the rotations observed in Miocene rocks were assumed by Reid et al. (1991) to have occurred between approximately 11 and 4.5 my. Despite the low number of sites measured in the eastern part of the PRVI block, GPS data seems to 
support the conclusion that the counterclockwise rotation has ceased (Jansma et al., 2000). Offshore seismic profiles were interpreted to document a change from extension to shortening across the Puerto Rico trench (Larue and Ryan, 1998).

Another late Neogene geodynamic change has been postulated for the Anegada passage with extensional movements changing to dextral transtensional in the Pliocene (Jany et al., 1987; 1990; Mauffret and Jany, 1990) (Fig. 1). Our analysis of the fracturing of northwestern Puerto Rico (in the prolongation of the Mona rift) will allow to choose between these models and to determine at what intervals major geodynamic changes occurred from the Eocene to recent.

\section{EOCENE TO RECENT EVOLUTION OF ROCK FRACTURING IN NW PUERTO RICO}

Puerto Rico is constituted by strongly folded and faulted early Cretaceous-Eocene volcanic arc rocks unconformably overlain along the north and south coasts by weaklydeformed, Oligocene-Pliocene siliciclastic rocks and platform carbonates (Fig. 3).

Structure of Cretaceous-Eocene arc basement rocks.

The Cretaceous to Eocene volcanic, plutonic, and metasedimentary volcanic arc units of Puerto Rico were deformed during late Eocene to earliest Oligocene time (Dolan et al., 1991). Faults trend mainly E-W to NW-SE (Monroe, 1969; Bawiec, 2001) (Fig. 3).

Two main fault zones are usually distinguished: the $\sim 8 \mathrm{~km}$ wide Southern Puerto Rico Fault Zone (SPRFZ) and the diffuse Northern Puerto Rico Fault Zone (NPRFZ) in northeastern Puerto Rico. Both faults underwent sinistral strike-slip motions in Eocene times in agreement with the general left-lateral oblique collision zone of the Greater Antilles (Pindell and Barrett, 1990; Gordon et al., 1997).

Southern Puerto Rico fault zone.

In the southeastern extremity of the SPRFZ, Erikson et al. (1990) found fault striations in mainly Eocene rocks compatible with E-W compression and in agreement with the left-lateral deformational model (fig. 3a). Erikson et al. (1990) also found reverse faults yielding NNE-trending compression (fig. 3a), which is in agreement with the presence of northeast-directed thrust structures. These thrust structures are compatible with the NNW-SSE to NNE-SSW trends of compression characterized by Larue et al. (1998) in north-central Puerto Rico (Fig. 3a). Along the Cerro-Goden fault zone (fig. 3b), Mann et al. (this volume) found evidence for recent right-lateral displacement of geomorphic features.

In Eocene rocks of northwestern Puerto Rico near the Cerro-Goden fault trend, we measured fault planes with striations and clear sense indicators including stratigraphic 
offsets, calcite steps, and Riedel fractures. Steeply-dipping bedding planes strike E-W to NW-SE (cf. the dashed lines in on stereo diagrams in Figure 3) in agreement with many Eocene and older fold axes trends in the island (e.g. Erikson et al., 1990).

Paleostress computation using all strike-slip and reverse faults measured in the sites 1 to 6 from Eocene basement rocks near the Cerro-Goden fault yield NNE-SSW compressional trends (Fig. 3). Commonly, from the symmetry of fault planes with bedding planes and the plunge of the paleostress axes, it is possible to infer that faulting occurred before, during and after the folding (e.g. Hippolyte et al., 1996). At sites with vertical bedding planes in Eocene rocks (sites 5, 4, 3, and 2 - Fig. 3), we could not distinguish if observed normal faults are strike-slip faults that have been tilted $90^{\circ}$ or recent normal faults reflecting EW extension. However, at site 6, compressional faults have been tilted to the north and some reverse faults are now horizontal or north-dipping normal faults. We conclude, from this observation and from the systematic perpendicularity of the compressional trend with the strike of the bedding planes, that NNE-trending compression is the main event responsible for the ESE-trending folding in western Puerto Rico (Fig. 3a).

Deformation of the Neogene carbonate platform of Puerto Rico

In northern Puerto Rico, the pre-Oligocene faulted basement is unconformably overlain by a tabular $4^{\circ}$ to $8^{\circ}$ northward-dipping sequence of mainly shallow-water limestone. This tilted carbonate platform extends offshore to $4000 \mathrm{~m}$ below sea level at a latitude of about $19^{\circ} \mathrm{N}$ (Moussa et al., 1987; van Gestel et al., 1998) (fig. 2). Together with the carbonates outcropping on the southern side of the island, this tilted platform is interpreted as part of an about $120 \mathrm{~km}$ wide arch formed from post Eocene to late Neogene times and resulting from north-south shortening (Dillon et al., 1994; van Gestel et al., 1998).

Offshore of northern Puerto Rico, this platform is remarkably free of any faults or folds except a few southwest-dipping recent normal faults near the Mona rift (van Gestel et al., 1998). Onshore, Monroe (1980) mapped two minor faults in north central Puerto Rico and four southwest-trending faults in the northwestern corner of the island (fig. 3b).

In the northwestern corner of the island, we measured 125 faults with striations and a clear sense motion that were present in Miocene carbonates. Sites 7 and 12 (Fig. 3b) in the Cibao Formation revealed only normal faults (confers the diagrams in figures 3 and 4). Based on field observations and on paleostress analyses we distinguish two fault generations.

First we recognize a N-S extension ( $\sigma 3$ trending NNW to NNE). At site 12 (fig. 3 ), this extension corresponds to pre-lithification faulting; at site 7 this extension corresponds to syndepositional and sealed faults with meter-scale offsets (Fig. 4). 
Second, we recognize an extension with $\sigma 3$ trending E-W to ESE (figs. 3 and 4) that corresponds to mainly N-S trending faults cross-cutting and offsetting the older syndepositional faults (Fig. 4).

This analysis shows that the stress field has evolved from Eocene to recent times. We conclude that the NNE-trending compression (fig. 3), that could have been responsible for the arching of the platform (van Gestel et al., 1998), characterize only the Eocene-Oligocene collisional event because: 1) the large-scale folds and thrusts affecting pre-Oligocene arc basement do not cut the overlying carbonate platform; and 2) we did not find evidence for compressional faulting in the Neogene cover. In contrast, we find that from early Miocene to recent the stress field is extensional.

\section{RECENT FAULTING OF AGUADILLA AREA IN NORTHWESTERN PUERTO RICO}

The regularity of the north-dipping monocline of platform carbonates is interrupted at the northwestern corner of Puerto Rico near the probable southwestern prolongation of the Mona Canyon (Fig. 3). Near Aguadilla, four SE-trending faults displace Neogene platform carbonates down to the east from 0-25m (Monroe, 1969). However, the main structure deforming the $4^{\circ}$-north-dipping monocline is a down to the west (coast) monoclinal flexure in bedding of more than $125 \mathrm{~m}$ (Figs. 5 and 6).

At sites 8, 9 and 10 on Figure 5, we have measured west-dipping bedding planes (cf. dashed lines in the diagrams of figures 5 and 6). Their unusual 10 to $20^{\circ}$ westward dips result from a combination of: 1 ) the general $4^{\circ}$ northward dip; 2) the effect of the regional flexure to the WSW (3-4 $)$; and 3) local tilts resulting from slip on SSE-trending faults (Fig. 5). The regional flexure in bedding trends approximately NNW-SSE and is parallel to the faults mapped by Monroe (1969) (Figs. 3b and 5). To the west of one of these faults, we observe on a DEM north-trending geomorphic lineaments clearly visible despite the karst topography (fig. 6). They form a horsetail splay suggesting a right lateral component on the main fault trending NW-SE (Figs. 5 and 6).

The fault zone in a quarry at site 8 (Fig. 5 ) is represented by large fault planes that show only normal slip and indicate an extension with $\sigma 3$ trending E-W. At site 11 , we observed another large fault as mapped by Monroe (1969) (Fig. 5). There, multiple normal faults over a few meters correspond to an extension with $\sigma 3$ trending ESE (upper right diagram in Fig. 5) and secondary faults correspond to a strike-slip state of stress with also an ESE-trending $\sigma 3$ axis (lower right diagram in Fig. 5). These two stress states are related by a permutation, or switch, in the $\sigma 1$ and $\sigma 2$ axes (Angelier and Bergerat, 1985) (fig. 5). Such stress permutations commonly occur during a same tectonic event (Hippolyte et al., 1992). 
At site 11, the ESE-WNW trend of $\sigma 3$ implies a dextral component on the normal movement of the main fault (Fig. 5). Considering its NW-SE trend, the main fault is probably a pre-Oligocene arc basement fracture reactivated. We interpret the stress permutation as a stress perturbation resulting from the propagation of this fault through the upperlying carbonates and the accommodation of this oblique movement by pure normal and pure strike-slip neoformed faults.

Site 10 is in the Aguada limestone (Fig. 5). In contrast with the Cibao formation which contains clay and marl levels the upperlying Aguada limestone was strongly karstified. With such karst erosion, the striated surfaces should have been partly or totally dissolved. However at karst outcrops near Aguadilla, we observed unweathered planar faults with fresh striations and styloliths (fig. 6). The fault planes cross-cut the karstified limestone, which explains the large dispersion in the fault attitudes in the diagram of Figure 6. Despite the irregular shape of the fault surfaces, all faults are compatible with an extension with E-W $\sigma 3$ axis similar to those reconstructed in the other sites of Aguadilla area (Fig. 5). This faulting that clearly post-dates the karst is therefore very recent because the arching and uplift of this area of the island postdates the Camuy limestones attributed to the early Pliocene (Moussa et al. 1987).

Similar to other sites of the Aguadilla flexure, fracturing of site 9 reveals only extension with an E-W orientation of $\sigma 3$ (Fig. 5). Considering that the main faults of Aguadilla area are trending NW-SE, and are therefore oblique to this trend of $\sigma 3$ and parallel to pre-Oligocene arc basement faults (fig. 3a), we interpret these faults as typical NW-trending basement faults that has been reactivated with a normal-dextral motion. Reactivation generated local stress permutations in order to accommodate oblique slip in the previously unfractured carbonate cover. The existence of the flexure lowering the carbonate platform to the WSW also support this interpretation of influence of the prefractured arc basement. This flexure is interpreted as due to a west-dipping basement fault, inherited from the Eocene deformation (fig. 3a), and reactivated as a normal fault with some superficial, conjugate and east-dipping faults (Fig. 5).

The horsetail splay of the main fault (Fig. 5), its curving to the west, and our microtectonic analysis, indicate that it is the termination of a west dipping normal-dextral fault that continues offshore toward the Mona rift (Fig. 2). We conclude that field data confirms that faults of the Mona rift extends onshore onto Puerto Rico near Aguadilla. The recent age of the fault termination, which is supported both by its morphology and the presence of post-karst striations, is in agreement with a ongoing opening of the Mona rift. Our fault slip measurements indicate that its opening direction is E-W and that the southeast trend of the southern part of this rift, offshore and onshore, results from the reactivation of SE-trending basement faults of Eocene age (Fig. 2). 


\section{DISCUSSION: MODEL FOR THE PRESENT DEFORMATION OF THE PUERTO RICO AREA}

The E-W opening of the Mona rift and our preliminary result in southern Puerto Rico (i.e., SE-trending sinistral transtension (Fig. 7) postdating NNE-trending dextral transtension) are not compatible with a present counterclockwise rotation of the PRVI microplate. As shown above, the stress field has evolved since Eocene times. We can reconstruct the Cenozoic history of the island in three tectonic stages.

The orogenic event that affected the northern Caribbean island arc in Paleogene times was characterized in western Puerto Rico by a NNE direction of compression (fig. 3). Note that this direction was NE-SW before the Miocene-Pliocene counterclockwise rotation of the island.

From late Oligocene to recent times, our fault analysis indicates only extension. During deposition of the Neogene carbonate platform and in particular during the early Miocene (Fig. 5), $\sigma 3$ is trending N-S. Despite the large $(>1000 \mathrm{~m})$ variations of thickness of the carbonate platform, normal faults are remarkably rare offshore north Puerto Rico (Masson and Scanlon, 1991; van Gestel et al., 1998) indicating that this stress field did not generate large structures. The N-S strike of $\sigma 3$ suggests that this extensional stress field represent a diffuse post-orogenic extensional collapse induced by the presence in front of Puerto Rico of the free-face of the subducting North American plate. As a model of counterclockwise rotation of Puerto Rico predicts possible extension in the Puerto Rico Trench (Masson and Scanlon, 1991), we cannot exclude that this N-S extension is a result of the initiation of the rotation which mainly occurred between 10 and 4 my.

For the late Pliocene-Quaternary period we do not found any evidence of compression that would have generated an arching of the platform (van Gestel et al., 1998). This conclusion seems valid for most of the island according to another paleostress investigation in the Neogene carbonates of southern Puerto Rico (Hippolyte and Mann, 2003). This suggests that the $4^{\circ}$ Pliocene tilt of the carbonate platform north of Puerto Rico (Moussa et al., 1987; van Gestel et al., 1998) might result from tectonic erosion (e.g. Birch, 1986) rather than from compression. In contrast, we found recent normal faulting at the onshore extension of the Mona rift that supports its present-day activity onland in Puerto Rico. This extensional deformation contrasts with the compressional deformation of a carbonate platform of similar age in northern Hispaniola (e.g. Calais and Mercier de Lepinay, 1991) and support that the Mona rift is an incipient plate boundary forming in response to collisional processes (e.g., Mann et al., in press).

The average trend of $\sigma 3$ is $N 92^{\circ} \mathrm{E}$, which implies a right-lateral component on the displacement of SE-trending normal faults in the southern Mona rift (Fig. 2). Moreover it 
suggests that the mainly dextral late Holocene ESE-trending Cerro-Goden fault (Fig. 2; Mann et al., this volume) is also part of the fault termination of the Mona rift (Fig. 7) and could be interpreted as a transfer fault. On Figure 2, one can note that the steepest wall of the Mona rift is its eastern side, where there are the largest normal displacements (van Gestel et al., 1998 ; Mann et al., 2002). In the southern part of the Mona rift, the main scarp trends NW-SE and is in agreement with the structural grain of the Pre-Oligocene basement. The occurrence of recent deformation at the prolongation of the northeastern scarp (fig. 5), on the Cerro-Goden fault at the prolongation of another SW-dipping scarp (fig. 2), and between these two zones (fig. 3b), indicates that all the northwestern side of the island is an area of diffuse normal oblique faulting representing the southeastern termination of the Mona rift (fig. 2 and 7).

The data presented here supports the hypothesis that differences in velocities between Hispaniola and Puerto Rico leads to extension in the Mona Passage (Vogt et al., 1976). This model is now confirmed by GPS measurements that indicate slower velocities in Hispaniola than in Puerto Rico relative to stable North America (Jansma et al., 2000) (fig. 1). However, in the Hispaniola convergent zone, GPS velocities may mostly represent elastic strain accumulation on seismic faults. To determine the real movement of eastern Hispaniola one must integrate the co-seismic slips of every seismic fault, which at this moment is only known for the Septentrional fault $(9+/-3 \mathrm{~mm} / \mathrm{yr}$, Prentice et al., submitted).

Jansma et al. (2000) tried to deduce the actual motion of Hispaniola from 2-D elastic modeling and proposed that Hispaniola is moving 5+/-4 mm/yr slower than Puerto Rico. They concluded that the direction of this divergent motion is around east-west with a possible northward component predicting minor left-lateral slip along the N-S trending faults of the Mona rift.

Our observation of recent normal faulting is in agreement with this conclusion of differential velocities between Hispaniola and Puerto Rico, but the computed direction of $\sigma 3\left(\mathrm{~N} 92^{\circ} \mathrm{E}\right)$ does not seems to confirm the northward component of motion predicted from this 2-D elastic strain modeling. Note that this average trend of $\sigma 3$ in northwestern Puerto Rico is between the SE-trend of the T axes of the two extensional focal planes mechanisms of the Mona rift area and the ENE-trends of the GPS vectors (fig. 1). Even if this orientation was obtained at a rift termination where oblique slips on large faults can generate stress perturbations and rotate the $\sigma 3$ axis, its perpendicularity with the main northern part of the rift suggest that the stress rotation is small and that this trend is close to the opening direction of the Mona rift (fig. 7).

To generate an E-W opening we suspect that the real motion of Hispaniola relative to North America is not more easterly than the motion of Puerto Rico (Jansma et 
al., 2000), but more northerly (fig. 7). This inference is in agreement with 3-D modeling of elastic strain accumulation resulting from the motion of the Caribbean plate on four faults in Hispaniola (Mann et al., 2002). These GPS results and modeling point out that a significant amount of fault reverse motion must exist. If coseismic NE-SW reverse movements are added to the elastic strain accumulation on mostly strike-slip faults (Fig. 1), the longterm movement of Hispaniola is more northward than the GPS vectors indicate (Fig. 1).

In the same way, the SE-trending sinistral transtension on the southern margin of Puerto Rico, as indicated by our preliminary fault slip measurements in South Puerto Rico and focal plane mechanisms (fig. 1, McCann and Lithgow-Bertelloni, this volume) might result from a slower and more northerly long-term motion of Puerto Rico than the Lesser Antilles (relative to fixed North America) (fig. 7). Despite the short time of observations and the absence of large earthquakes, GPS measurements of Jansma et al. (2000) agree with a difference in velocities between Puerto Rico and the Caribbean Plate.

Acknowledgments: This work was partly supported by the University of Savoy, France and by the University of Texas at Austin. 
Fig. 1: Major structures, seismicity and GPS motions of the northeastern Caribbean plate margin. Structures are from Masson and Scanlon (1991) and van Gestel, et al. (1998) Focal plane mechanisms for depth $<35 \mathrm{~km}$ are from the Harvard Centroid Moment Tensor catalogue and from Huerfano (1995) (south of the Muertos Trough). Historical seismicity is from Pacheco and Sykes (1992). GPS velocities relative to North America are from Jansma et al. (2000) and Mann et al. (2002).

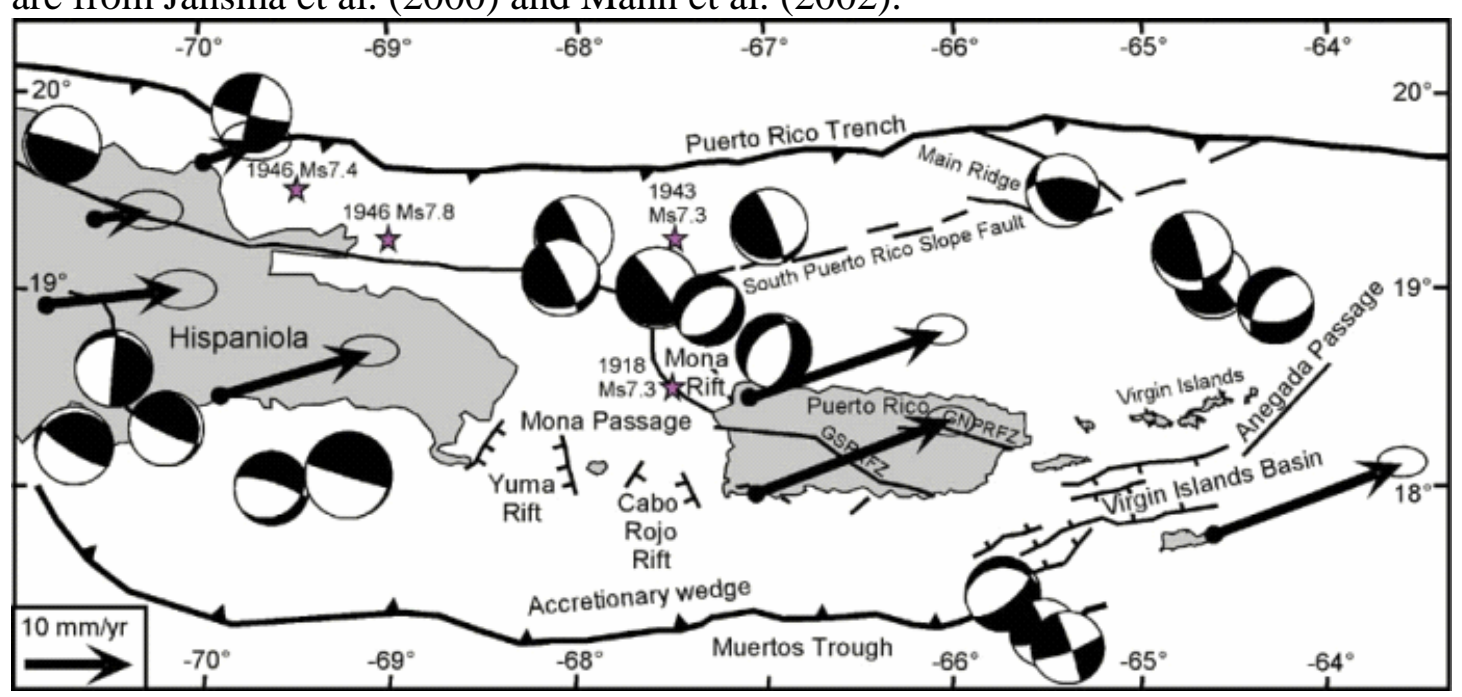


Fig. 2: Shaded view of the Mona rift and western Puerto Rico and location of the area of interest (figure 3b). Illumination is from the SSE. Contours every $200 \mathrm{~m}$. MP: exposed Miocene-early Pliocene platform carbonates. Q: quaternary deposits. CGF: Cerro-Goden active fault (Mann et al., this volume). The Mona rift trends N-S in the north, then turns to the southeast toward the northwestern corner of Puerto Rico. Note NNW-trending faults cutting the Neogene carbonates in NW Puerto Rico that are close to the offshore steep eastern wall of the rift.

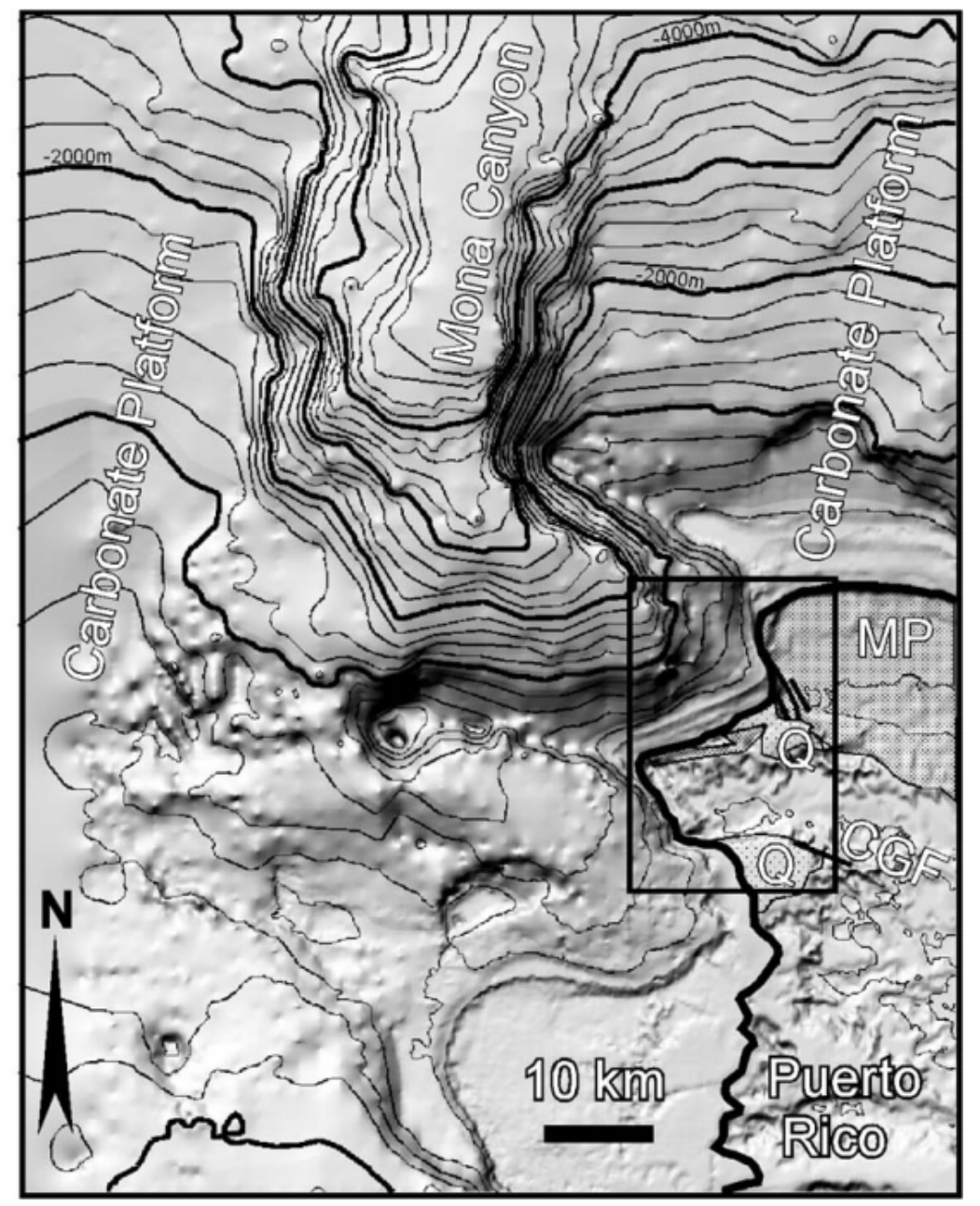


Fig. 3: Location of the studied area and Schmidt diagrams of faults measured in the Miocene platform carbonates and in the folded Eocene basement. A. Structural sketch of western Puerto Rico (modified from Bawiec, 2001) with directions of compression determined by Erikson et al. (1990) and Larue et al. (1998) from faults slip measured in Cretaceous-Lower Tertiary formations. SPRFZ: Southern Puerto Rico Fault Zone; NPRFZ: Northern Puerto Rico Fault Zone. B. Structural sketch of the studied area (modified from Monroe, 1980) with directions of compression $(\sigma 1)$ and extension $(\sigma 3)$ derived from this study. CGF: Cerro-Goden Fault.

For each site the Schmidt diagrams lower hemisphere show the measured striated fault planes and the computed stress axes. Five-branch star $=\sigma_{1}$ (maximum principal stress axis); four-branch star $=\sigma_{2}$ (intermediate principal stress axis); three-branch star $=\sigma_{3}$ (minimum principal stress axis); bedding planes as broken lines.

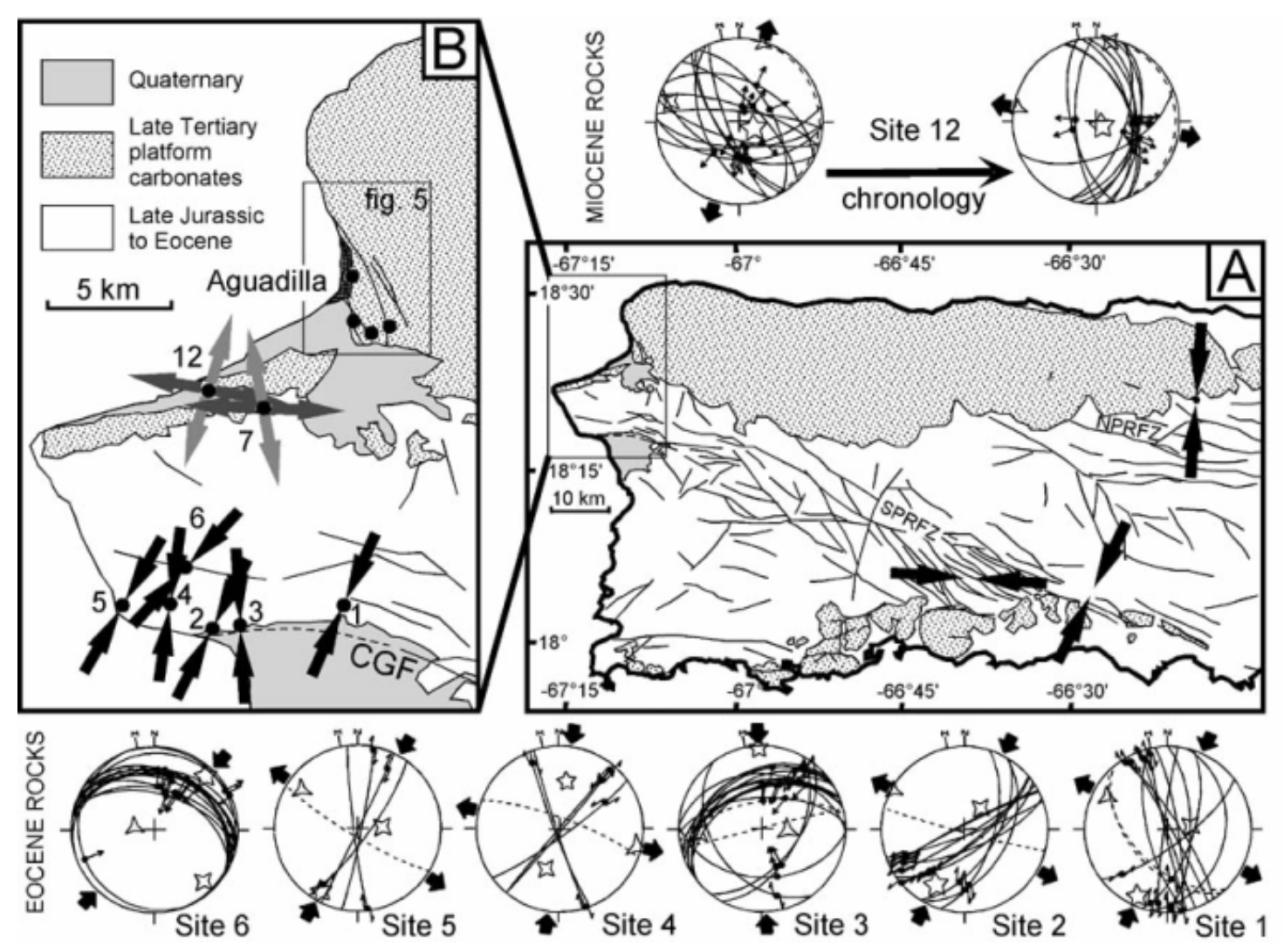


Fig. 4: Cross-cutting relationships of normal faults at site 7. White lines show the base of stratigraphic layers.

E-W normal faults (in black), corresponding to a NNW-SSE extensional event, are syndepositional. Their activity during the deposition of the Cibao Early Miocene carbonates is attested by variations in thickness of the carbonates layers and by the upper layer that seals the faulted blocs. The presence of oysters at an uplifted fault-block crest confirms the syn-depositional faulting interpretation. It shows that faulting had modified the sea floor morphology in creating a local high favorable for their life.

$\mathrm{N}-\mathrm{S}$ normal faults (in red), corresponding to a more recent E-W extensional event, offset the syndepositional faults. $\mathrm{E}$ and $\mathrm{W}$ indicate the dip directions of the fault planes.
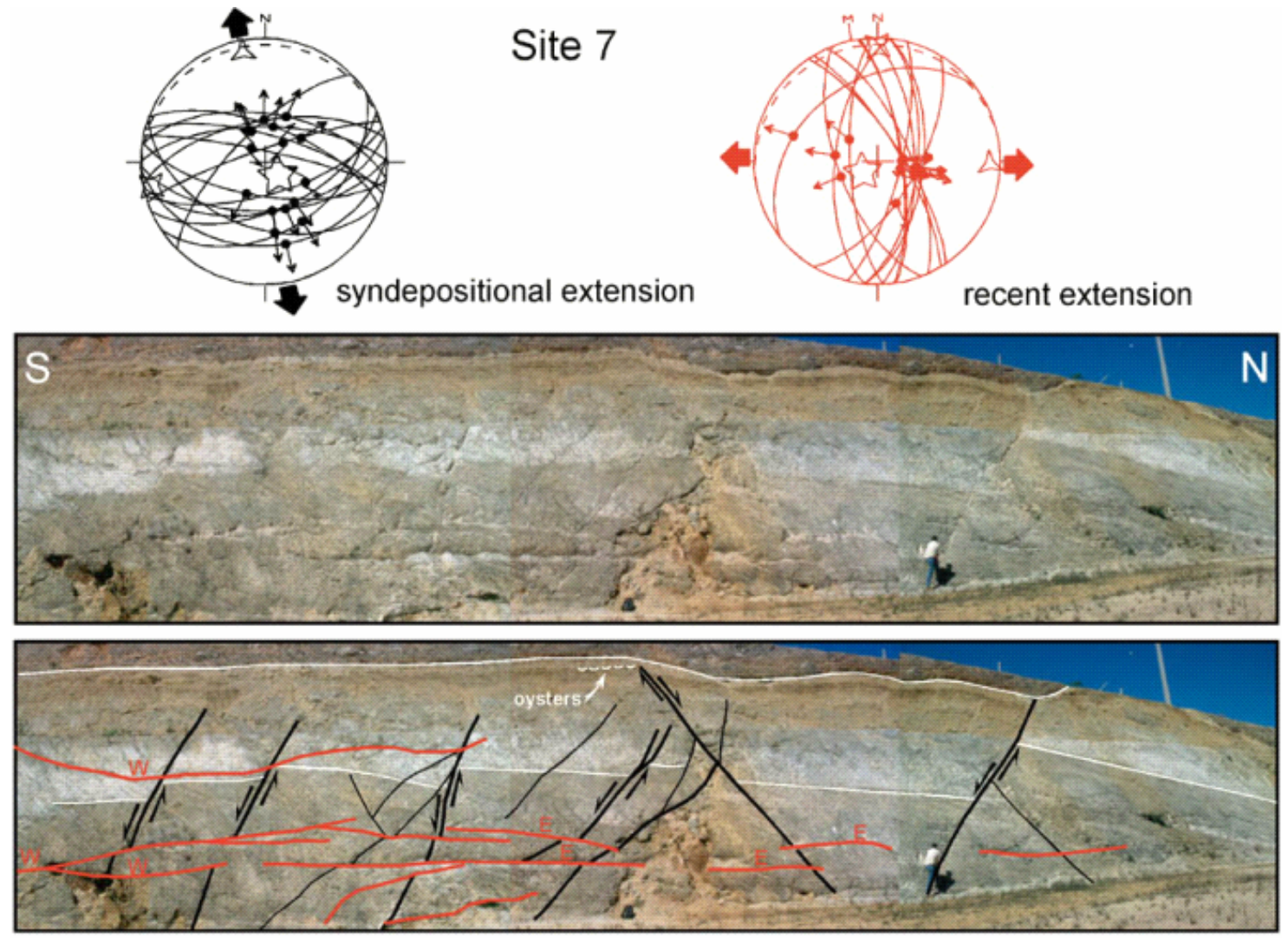
Fig. 5: Morphostructural sketch of the Aguadilla area (location in fig. 3b) and results of stress inversion from fault planes measured in the Miocene limestones. The geological map (Monroe, 1969) is draped on a USGS 30m Digital Elevation Model with illumination from the NE. Stratigraphic contours and NW-trending faults are from Monroe (1969). The Cibao formation is Early Miocene, the Aguada limestone is early-middle Miocene and the Aymamon chalk is middle-late Miocene (Seiglie and Moussa, 1984). Note the N$\mathrm{S}$ morphological lineaments of the karst eroded Aguada limestone that branch on a NWSE fault mapped by Monroe. Lineaments are interpreted as part of a horsetail splay at the end of an offshore fault of the Mona rift.

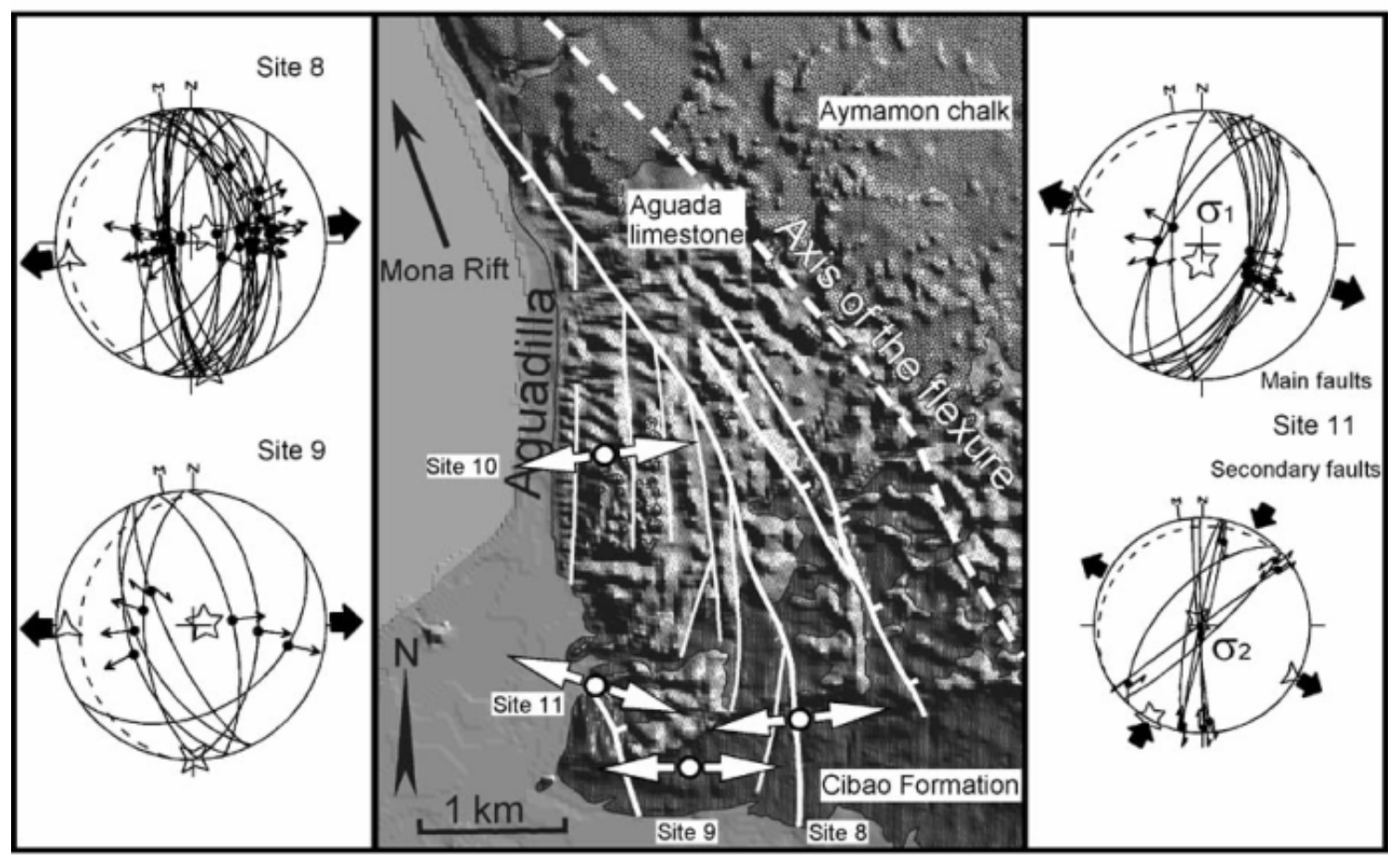


Fig. 6: 3D-view of fig. 5 (vertical exaggeration: 3:1) with location and fault diagram of site 10. This view shows the local flexure toward the SW of the general north-dipping platform carbonates (cf. the dip of the contact between the Cibao and the Aguada formations). Note the karst topography in the Aymamon and Aguada carbonates. The faults of site 10 are measured in the highly karst eroded Aguada limestone. The striations postdate the karst erosion as shown by the irregularity of the striated surfaces crossing the weathered, vuggy limestone. This is illustrated by the various fault attitudes in the Schmidt diagram.

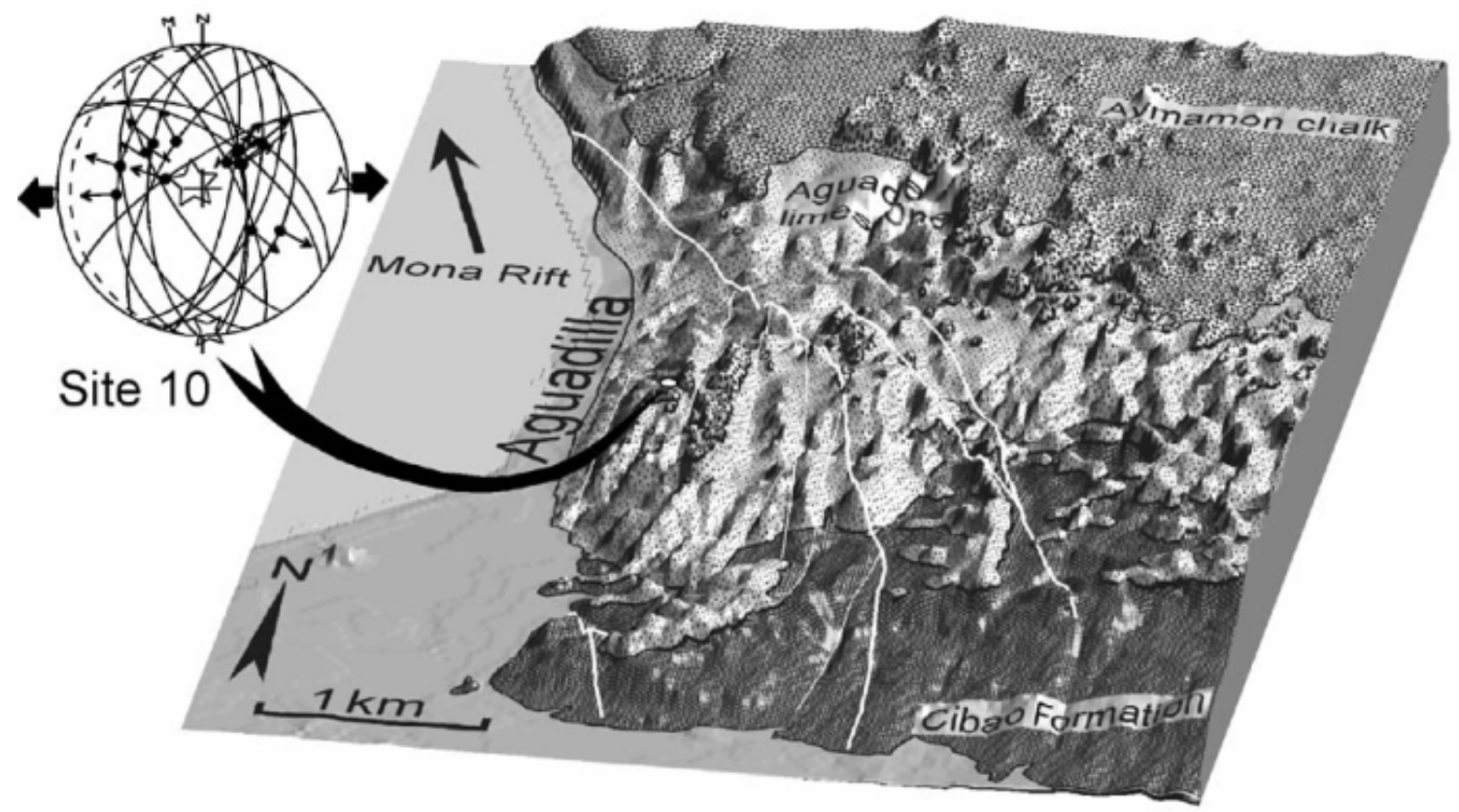


Fig. 7: Conceptual model for the Pliocene-Quaternary geodynamics of Puerto Rico. Mona rift opens E-W. The south of Puerto Rico is deformed by about SE-trending extension (according to the focal planes mechanisms and to our preliminary results of fault slip measurements) which indicate sinistral transtension on this E-W margin. Inset: We suppose that the origin of these openings (large arrows) lies in small differences in orientation and velocities of the movements (thin arrows) of the Hispaniola (Hisp.), Puerto-Rico Virgin Islands (P.R.) and Caribbean plates (Carib. P.).

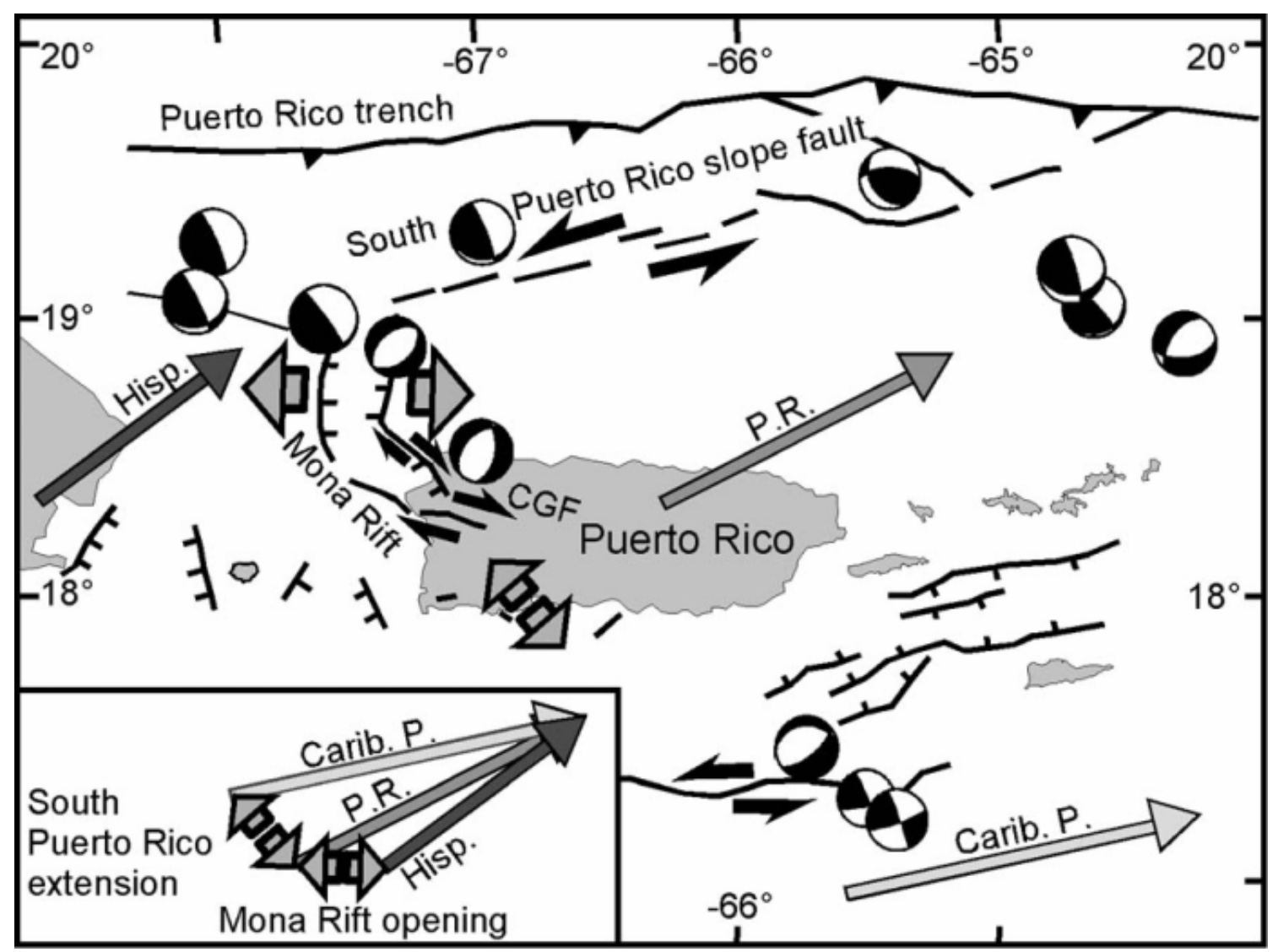


Table 1 : Paleostress tensors computed from fault-slip data. Sites of figures. 3, 4, 5, and 6. Stress regimes: $\mathrm{C}=$ compressional, $\mathrm{S}=$ strike-slip, $\mathrm{E}=$ extensional. $\sigma 1, \sigma 2, \sigma 3$ : maximum, intermediary and minimum principal stress axis respectively. tr., pl.: trend (north to east) and plunge in ${ }^{\circ}$ of the stress axes. $\Phi=(\sigma 2-\sigma 3) /(\sigma 1-\sigma 3)$. ANG $=$ average angle between computed shear stress and observed slickenside lineation $\left({ }^{\circ}\right)$. RUP= quality estimator $(0 \leq \mathrm{RUP} \leq 200)$ taking into account the relative magnitude of the shear stress on fault planes (cf. Angelier, 1990).

\begin{tabular}{|c|c|c|c|c|c|c|c|c|c|c|c|c|c|}
\hline site & formation & age of & stress & number & $\sigma 1$ & & $\sigma 2$ & & $\sigma 3$ & & $\Phi$ & ANG & RUF \\
\hline & & rocks & regime & $\begin{array}{c}\text { of } \\
\text { faults }\end{array}$ & tr. & pl. & tr. & pl. & tr. & pl. & & & \\
\hline 1 & Culebrinas & Eocene & $\mathrm{S}$ & 12 & 204 & 13 & 81 & 67 & 299 & 18 & 0.47 & 11 & 33 \\
\hline 2 & Culebrinas & Eocene & $S$ & 12 & 207 & 26 & 37 & 64 & 299 & 4 & 0.23 & 13 & 40 \\
\hline 3 & Culebrinas & Eocene & C & 16 & 357 & 3 & 266 & 25 & 94 & 65 & 0.68 & 12 & 28 \\
\hline 4 & Culebrinas & Eocene & $S$ & 5 & 8 & 42 & 199 & 48 & 103 & 6 & 0.71 & 8 & 25 \\
\hline 5 & Culebrinas & Eocene & $S$ & 4 & 210 & 14 & 87 & 66 & 305 & 20 & 0.43 & 24 & 55 \\
\hline 6 & Culebrinas & Eocene & C & 16 & 43 & 12 & 137 & 15 & 277 & 70 & 0.32 & 14 & 43 \\
\hline 7 & Cibao & $\begin{array}{l}\text { early } \\
\text { Mioc. }\end{array}$ & $E$ & 16 & 134 & 77 & 258 & 7 & 349 & 11 & 0.23 & 9 & 31 \\
\hline 7 & Cibao & $\begin{array}{l}\text { early } \\
\text { Mioc. }\end{array}$ & E & 14 & 232 & 78 & 180 & 7 & 92 & 9 & 0.28 & 8 & 29 \\
\hline 8 & Cibao & $\begin{array}{l}\text { early } \\
\text { Mioc. }\end{array}$ & E & 27 & 60 & 79 & 172 & 4 & 263 & 10 & 0.45 & 9 & 32 \\
\hline 9 & Cibao & $\begin{array}{l}\text { early } \\
\text { Mioc. }\end{array}$ & E & 7 & 82 & 82 & 179 & 1 & 269 & 8 & 0.45 & 8 & 23 \\
\hline 10 & Aguada & $\begin{array}{l}\text { early- } \\
\text { middle }\end{array}$ & E & 15 & 303 & 84 & 178 & 4 & 87 & 5 & 0.22 & 15 & 37 \\
\hline 11 & Cibao & $\begin{array}{l}\text { Mioc. } \\
\text { early } \\
\text { Mioc. }\end{array}$ & $E$ & 12 & 185 & 79 & 19 & 10 & 288 & 2 & 0.47 & 4 & 19 \\
\hline 11 & Cibao & $\begin{array}{l}\text { early } \\
\text { Mioc. }\end{array}$ & $S$ & 8 & 209 & 2 & 322 & 85 & 119 & 5 & 0.43 & 11 & 37 \\
\hline 12 & Cibao & $\begin{array}{l}\text { early } \\
\text { Mioc. }\end{array}$ & E & 11 & 130 & 83 & 10 & 4 & 280 & 6 & 0.32 & 9 & 25 \\
\hline 12 & Cibao & $\begin{array}{l}\text { early } \\
\text { Mioc. }\end{array}$ & $E$ & 14 & 115 & 74 & 286 & 15 & 17 & 2 & 0.26 & 11 & 38 \\
\hline
\end{tabular}


References:

Angelier, J., 1990, Inversion of field data in fault tectonics to obtain the regional stressIII. A new rapid direct inversion method by analytical means. Geophys. J. Int., v. 103, p. 363-376.

Angelier, J., and Bergerat, F., 1983, Systèmes de contrainte et extension intracontinentale, Bull. Centr. Rech. Explor. Prod. Elf Aquitaine, v. 7, p. 137-147.

Bawiec, W.J., 2001, Geologic Terranes of Puerto Rico. in: Geology, Geochemistry, Geophysics, Mineral Occurrences and Mineral Ressource Assesment for the Commonwealth of Puerto Rico. U.S. Geological Survey Open-File Report 98-38 ed. W. Bawiec, p. 59-65.

Birch, F.S., 1986, Isostatic, thermal, and flexural models of the subsidence of the north coast of Puerto Rico. Geology, v. 14, p. 427-429.

Byrne, D.B., Suarez, G. and McCann, W.R., 1985, Muertos Trough subduction microplate tectonics in the northern Caribbean. Nature, v. 317, p. 420-421.

Calais, E., and Mercier de Lépinay, B., 1991, From transpression to transtension along the northern Caribbean plate boundary: Implications for the recent motion of the Caribbean plate. Tectonophysics, v. 186, p. 329-350.

Case, J. E. and Holcombe T. L., 1980, Geologic-Tectonic map of the Caribbean region, scale 1/2500000, Map I-1100, U. S. Geol. Surv. Misc. Investigation series.

DeMets, C., Jansma, P., Mattioli, G., Dixon, T., Farina, F., Bilham, R., Calais, E. and Mann, P., 2000, GPS geodetic constraints on Caribbean-North America plate motion: Geophysical Research Letters, v. 27, p. 437-440.

Dillon, W. P., Edgar, N.T., Scanlon, K. M. and Coleman, D. F., 1994, A review of the tectonic problems of the strike-slip northern boundary of the Caribbean plate and examination by GLORIA. In: J. V. Gardner, M. E. Field and D. C. Twichell (Editors), Geology of the United States' Seafloor: The view From GLORIA. Cambridge University Press, Cambridge, U.K., p. 135-164 
Dolan, J.P., Mann, P., de Zoeten, R., Heubeck, C., Shimora, J., and Monechi, S., 1991, Sedimentologic, stratigraphic, and tectonic synthesis of Eocene-Miocene sedimentary basins, Hispagnola and Puerto Rico. In: P. Mann, G. Draper and J.F. Lewis (Editors), Geologic and Tectonic Development of the North America-Caribbean Plate Boundary in Hispaniola. Special Pap. Geol. Soc. Am., v. 262, p. 1-28

Erikson, J.P.E., Pindell, J.L. and Larue, D.K., 1990, Mid-Eocene-Early Oligocene sinistral trancurrent faulting in Puerto Rico associated with formation of the northern Caribbean Plate Boundary Zone. Journal of Geology, v. 98, p. 365-384.

Fink, L.K. and Harrison, C.G.A., 1972, Palaeomagnetic investigations of selected lava units on Puerto Rico. Proceedings of the 6th Caribbean Geological Conference, p.379.

Gordon, M.B., Mann, P., Caceres, D. and Flores, R., 1997, Cenozoic tectonic history of the North America-Caribbean plate boundary zone in western Cuba. Journal of Geophysical Research, v. 102 (B5), p. 10,055-10,082.

Grindlay , N. R., Mann, P. and Dolan, J. F., 1997, Researchers investigate submarine faults north of Puerto Rico, EOS (Trans. Amer. Geophys. Union), v. 78, p. 404.

Hippolyte, J-C., Angelier, J. and Roure, F., 1992, Les permutations de contraintes dans un orogène: exemple des terrains quaternaires du sud de l'Apennin. C. R. Acad. Sci. Paris, t. v. 315, Série II, p. 89-95.

[16] Hippolyte, J-C. and Mann, P., 2003, Fracture analysis of Neogene rocks in Puerto Rico constrains Neogene-Quaternary microplate evolution of the northeastern Caribbean Plate. EGS-AGU-EUG Joint Assembly, Nice, France, April 2003.

Hippolyte, J-C. and Sandulescu, M., 1996, Paleostress characterization of the 'Wallachian phase' in its type area (southeastern Carpathians, Romania). Tectonophysics, v. 263, p. 235-248.

Huerfano, V., 1995, Crustal structure and stress regime near Puerto Rico, M.S. thesis, Univ. of Puerto Rico, Mayagüez.

Jansma, P. E., Mattioli, G. S., Lopez, A., DeMets, C., Dixon, T. H., Mann, P. and Calais, E., 2000, Neotectonics of Puerto Rico and the Virgin Islands, northeastern Caribbean, from GPS geodesy. Tectonics, v. 19, no. 6, p. 1021-1037. 
Jany, I., Mauffret, A., Bouysse, P., Mascle, A., Mercier de Lépinay, B., Renard, V. and Stephan, J.-F., 1987, Relevé bathymétrique Seabeam et tectonique en décrochement au sud des îles Vierges (Nord-Est Caraîbes). C. R. Acad. Sci. Paris, v. 304, p. 527-532.

Jany, I., Scanlon, K. M., and Mauffret, A., 1990, Geological interpretation of combined seabeam, Gloria and Seismic data from Anegada Passage (Virgin Islands, North Caribbean). Marine Geophysical Researches, v. 12, p. 173-196.

Ladd, J.W., Worzel, J.L. and Watkins, J.S., 1977, Multifold seismic reflection records from the Northern Venezuela Basin and the north slope of Muertos Trench, in M. Talwani and W.C. Pitman, eds., Island Arcs, Deep-Sea Trenches and Back-Arc Basins, American Geophysical Union: Washington D.C., p. 41-56

Larue D. K., Torrini Jr., R., Smith, A. L., and Joyce, J., 1998, North Coast Tertiary basin of Puerto Rico: From arc basin to carbonate platform to arc-massif slope, in Lidiak, E.G., and Larue, D.K., eds, Tectonics and Geochemistry of the Northeastern Caribbean: Boulder, Colorado, Geological Society of America Special Paper 322, p. 155-176.

Mann, P., et al., Late Quaternary faulting along the La Cadena mountain front (Cerro Goden fault zone), western Puerto Rico, this volume.

Mann, P., Taylor, F. W., Edwards R.L. and Ku, T. L., 1995, Actively evolving microplate formation by oblique collision and sideways motions along strike-slip faults : An example from the northeastern Caribbean plate margin. Tectonophysics, v. 246, p. 1-69.

Mann, P., Calais, E., Ruegg, J. C., DeMets, C., Jansma, P. E. and Mattioli, G., 2002, Oblique collision in the northeastern Caribbean from GPS measurements and geological observations. Tectonics, v. 21, no. 6.

Masson, D.G., and Scanlon, K.M., 1991, Neotectonic setting of Puerto Rico, Geological Society of America Bulletin, v. 103, no. 1, p. 144-154.

Mauffret, A. and Jany, I., 1990, Collision et tectonique d'expulsion le long de la frontière Nord-Caraïbe. Oceanologica acta, v. 10, p. 97-116.

McCann, W.R., Microearthquakes Clarify the Neotectonics of Puerto Rico and the U.S. Virgin Islands, Northeastern Caribbean, this volume. 
McCann, W.R., Feldman, L., and McCann, M., Catalog of Felt earthquakes for Puerto Rico and Neighboring Islands 1492-1899 with Additional Information for some 20th Century Earthquakes, this volume.

McCann, W.R., and Lithgow-Bertelloni, C.L., Origin, and Neotectonics of the Anegada Trough, Northeastern Caribbean, this volume.

Mercado, A. and McCann, W., 1998, Numerical simulation of the 1918 Puerto Rico tsunami, J. Nat. Hazards, v. 18, p. 57-76.

Monroe, W.H., 1969, Geologic map of the Aguadilla Quadrangle, Puerto Rico: U.S. Geological Survey Miscelllaneous Investigations Maps I-569, scale 1:20,000.

Monroe, W.H., 1980, Geology of the Middle Tertiary Formations of Puerto Rico. Geological Survey Professional Paper 953. 1 map, 93 pp.

Moussa, M. T., Seiglie, G. A., Meyerhoff, A. A., and Taner, I., 1987, The Quebradillas Limestone (Miocene-Pliocene), northern Puerto Rico, and tectonics of the northeastern Caribbean margin. Geological Society of America Bulletin, v. 99, p. 427-439.

Pacheco, J. F., and Sykes, L. R., 1992, Seismic moment catalog of large shallow earthquakes, 1900 to 1989, Bull. Seismol. Soc. Am., v. 82, p. 1306-1349.

Pindell, J. L., and Barrett, S. F., 1990, Geological evolution of the Caribbean region: A plate-tectonic perspective. In: G. Dengo and J. E. Case (Editors), The Geology of North America, vol. H, The Caribbean Region. Geol. Soc. Of Am., Boulder, Colorado, p. 405432.

Reid, J. A., Plumley, P. W., and. Schellekens, J. H, 1991, Paleomagnetic evidence for Late Miocene counterclockwise rotation of north coast carbonate sequence, Puerto Rico. Geophys. Res. Lett., v. 18, p. 565-568.

Schell, B. A. and Tarr, A. C., 1978, Plate tectonics of the northeastern Caribbean Sea region. Geologie en Mijnbouw, v. 57, p. 319-324.

Seiglie, G. A., and Moussa, M. T., 1984, Late Oligocene-Pliocene transgressiveregressive cycles of sedimentation in northwestern Puerto Rico. in: J. S. Schlee (ed) 
Interregional unconformities and hydrocarbon accumulation, AAPG Memoir, v. 36, p. 8995.

Van Fossen, M. C., Channell, J. T., and Schellekens, J. H., 1989, Paleomagnetic evidence for Tertiary anticlockwise rotation in southwest Puerto Rico. Geophys. Res. Lett., v. 16, p. 819-822.

van Gestel, J. P., Mann, P., Dolan, J. F. and Grindlay, N. R., 1998, Structure and tectonics of the upper Cenozoic Puerto Rico-Virgin Islands carbonate platform as determined from seismic reflection studies. J. Geophys. Res., v. 103, p. 30,505-30,530.

Vogt, P. R., Lowrie, A., Bracey, D. R. and Hey, R. N., 1976, Subduction of aseismic ridges: effects on shape, seismicity, and other characteristics of consuming plate boundaries, Spec. Pap. Geol. Soc. Am., v. 172, p. 1-59. 